\title{
INCREASE IN KNOWLEDGE AMONG YOUNG ADULT PARTICIPANTS REGARDING NUTRITION AFTER THE WEBINAR SEROTONIN 2021
}

\author{
I Putu Dharma Kresna ${ }^{1}$, Nisrina Nabila Raniasari ${ }^{1}$, Gabrielle Nathania Hanusi ${ }^{1}$, \\ Dewi Ratna Sari ${ }^{2 *}$ \\ ${ }^{2}$ Official email address: dewi-r-s@fk.unair.ac.id \\ ${ }^{1}$ Faculty of Medicine, Universitas Airlangga, Surabaya, Indonesia
}

${ }^{2}$ Department of Anatomy, Histology, and Pharmacology, Faculty of Medicine, Universitas Airlangga, Surabaya, Indonesia

\begin{abstract}
The COVID-19 pandemic has forced a lot of people, including Indonesian citizens to face various changes, adapt to the current situation, and implement new lifestyle habits. Measures have been taken to minimize the risk of COVID-19 transmission, such as implementing the health protocols which include washing hands, wearing masks, social distancing, avoiding crowds, and minimizing mobility. Furthermore, maintaining and increasing the body's immune system is crucial as an effort to prevent COVID-19 infection. One of the ways to increase the body's immune system is through a balanced diet and consuming nutritious food. Therefore, this research was conducted to analyze the community's comprehension about nutrition during the pandemic. This research was a descriptive analytic study. The data was collected twice, prior to- and following the intervention, using google form which contained several questions regarding nutritional knowledge. The number of participants which fulfilled the inclusion criteria includes 53 people aged 18-35 years old. There was a significant difference between the average knowledge related to the results of community knowledge before (46.25) and after (56.47) providing education $(\mathrm{p}=0.001)$ where there was an increase of $22.1 \%$. Education given through online webinar SEROTONIN 2021, improved the community's knowledge about nutritional health during the COVID-19 pandemic, especially in productive age.
\end{abstract}

Keywords: Balanced nutrition; COVID-19; nutrition; nutritional health; public health

\section{Introduction}

Severe Acute Respiratory Syndrome Coronavirus 2 (SARS-CoV-2) is a type of coronavirus that causes a respiratory disease called Coronavirus Disease-19 (COVID-19) (Sauer, 2021). SARS-CoV-2 was first detected in December 2019 in Wuhan, China, and on the $11^{\text {th }}$ of March 2020, the World Health Organization declared COVID-19 as a pandemic (World Health Organization (WHO), 2020). Coronavirus is known to spread through droplets and virus particles that are released if an infected person breathes, speaks, coughs, sings, or laughs. An infected person can potentially spread the disease to others starting from 2 days before the onset of symptoms up to 20 days after, depending on the immune system of others and the severity of the disease. 
Attempts to prevent the spread of COVID-19 includes wearing masks, social distancing, and avoiding crowds, as well as maintaining sanitation, especially hand hygiene (Sauer, 2021).

The COVID-19 pandemic has caused many changes in the lives of citizens worldwide, including Indonesians. A balanced and optimal nutrition is one of the contributing factors for maintaining the immune system in order to prevent COVID-19 infection. The human body requires energy that is obtained through a healthy diet to boost immunity against COVID-19. Knowledge on nutritional health is essential as an effort in optimizing the immune system to prevent COVID-19 infection (Kementerian Kesehatan Republik Indonesia (Kemenkes RI), 2020). Dewi et al. (2020) reported that $94 \%$ of people in productive age do not consume sufficient nutritious food during the pandemic (Dewi, Maemunah, \& Putri, 2020).

Adequate and balanced nutritional intake may help increase immunity. Recommendation for adequate daily nutritional intake includes macronutrients, such as carbohydrates from rice, corn, potato, and roots. Products derived from animals such as fish, chicken, meat, and eggs, as well as vegetable derived products such as beans and tofu are sources of proteins and minerals which are also essential. Fruits and vegetables which are sources of vitamins, minerals, and fibers should also be consumed daily. Daily water intake with a minimum of 8 glasses of water is also important (Kementerian Kesehatan Republik Indonesia (Kemenkes RI), 2020).

Megawati and Herawati (2021) conducted a study of assistance in achieving adequate nutritional intake during the COVID-19 pandemic for adults in urban settings. The study reported that only 55\% of participants had a positive attitude towards meeting the needs of animal protein consumption 3 times a day, according to recommendations from the Indonesian Association of Clinical Nutrition Specialists / Perhimpunan Dokter Spesialis Gizi Klinik Indonesia (PDGKI) (Megawati \& Herawati, 2021). As a matter of fact, adding the animal protein intake during the pandemic is a means of prevention against COVID-19 infection through boosting the immune system. Therefore, during the COVID-19 pandemic, the recommendation for animal protein intake is elevated to 75-100 g/day (Perhimpunan Dokter Spesialis Gizi Klinik Indonesia (PDGKI), 2020). Another study found that there was less than $80 \%$ of participants had a positive attitude in consuming fruits and vegetables (Megawati \& Herawati, 2021).

This webinar was held with the goal of improving knowledge on nutritional health to maintain the immune system during the COVID-19 pandemic as a preventive measure against COVID-19 infection. This research aim was to analyze the knowledge and comprehension of the participants regarding balanced nutritional intake before and after the webinar.

\section{Method}

The research was a descriptive-analytic study that used a One Group Pretest-Posttest Design. One Group means that examination was carried out in one class. The function of the pre-test and post-test is to evaluate the level of progress in the study. Therefore, no control group is used as a measurement (Irmawartini \& Nurhaedah, 2017).

One Group Pretest-Posttest Design was developed by measuring whether any intervention is applied (pre-test), and after that, measurements were performed once again (post-test). The first measurement was carried out to understand the knowledge and comprehension of the participant regarding the material for balanced nutritional intake to maintain the immune system during pandemic. After the results were obtained, the material can be given through an online webinar (Irmawartini \& Nurhaedah, 2017).

One of the interventions for the SEROTONIN 2021 webinar activity has the theme "Balance Nutrition Intake to Maintain Immunity During a Pandemic" which was held in July 2021. The presentation of the expert lasted for 60 minutes, with an allocation of 45 minutes presentation and 15 minutes for discussion and question and also answer sessions, along with the participant's filling out the pre-test and post-test. Evaluation of participants' knowledge was carried out by administering a questionnaire via Google Form before (pre-test) and 
after (post-test) the presentation of the material. Participants must answer 15 questions for approximately 10 minutes in the post-test and pre-test.

The Indonesian Central Statistics Agency reports that the percentage of the productive age population (15-64 years) in the 2020 population census data reaches $70.72 \%$ of the total population (Badan Pusat Statistik (BPS), 2021). The inclusion criteria for this study were young adult participants who attended the webinar, aged between 18-40 years old and filled out both the pre-test and post-test. The exclusion criteria for this study were participants outside the productive age range and did not complete both the pre-test and post-test. This study analyzed the participants' knowledge before and after delivering material regarding balanced nutritional intake to maintain immunity during a pandemic through pre-test and post-test scores containing 11 multiple-choice questions that had passed the validity test.

Data were analyzed using IBM SPSS version 23 and Microsoft Excel, presented in tabular form. Comparative test between the pre-test and post-test knowledge results using the Wilcoxon Signed Rank Test because the data distribution is not normal. The p-value used in this study was 0.05 , where the value was significant if $\mathrm{p}<0.05$.

\section{Results and Discussion}

The total participants were 191 people, with 100 participants filling out the pre-test and 91 participants filling out the post-test. A total of 65 participants filled both, but only 53 participants with an age range of 1835 years. The majority of participants aged 18-25 years were $96 \%$, and most of them were students, namely $81 \%$. The following is participant demographic data, as shown in Figure 1.

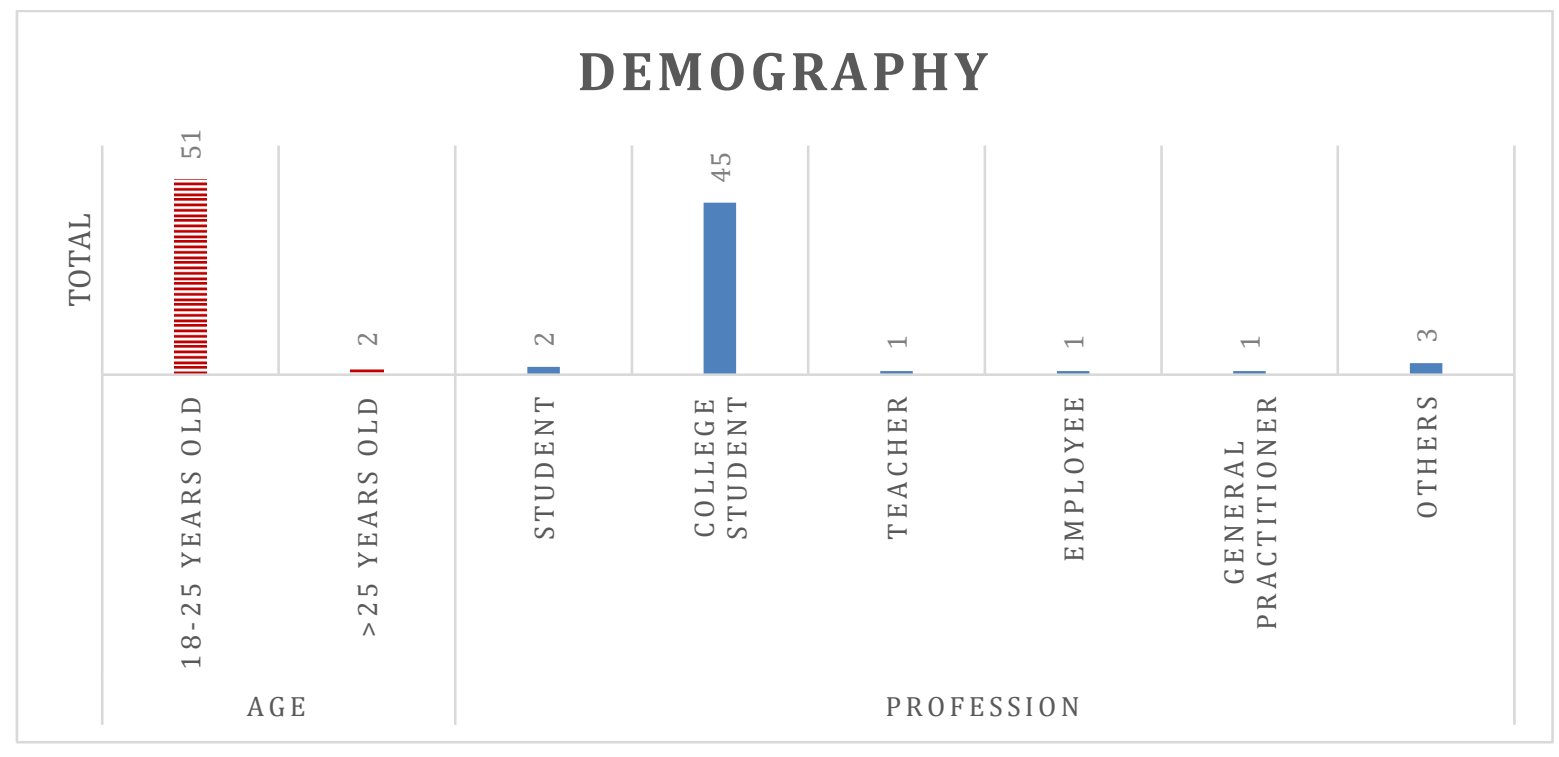

Figure 1. The Demography of the Participants

The validity test of the questions listed in the pre-test and post-test was carried out, and only 11 of the 15 questions passed the validity test. Table 1 shows an increase in the percentage of correct answers by participants in 10 of the 11 questions. The most increase percentage rate was found in question number 1 
regarding " Which of the following statement is incorrect regarding the interaction between nutrition and infection ", which is $25 \%$. There was a decrease in respondents' correct answers to number 3 with the question " The following statement which is correct regarding nutrition is " by $9 \%$. One of the factors that might have contributed to the decrease of the score was because participants did not know the correct answer so that the choices changed when filling out the post-test. This is due to the lack of information obtained related to nutrition.

Table 1. The percentage of correct answers in pre-test and post-test $(n=53)$.

\begin{tabular}{|c|c|c|c|}
\hline \multirow{2}{*}{ No. } & \multirow{2}{*}{ Questions } & \multicolumn{2}{|c|}{ Correct Answer $(\%)$} \\
\hline & & Pre-test & Post-test \\
\hline 1. & $\begin{array}{l}\text { Which of the following statement is incorrect regarding the interaction between nutrition and } \\
\text { infection }\end{array}$ & $28 \%$ & $53 \%$ \\
\hline 2. & The method to increase our immunity during a pandemic is & $75 \%$ & $81 \%$ \\
\hline 3. & The following statement which is correct regarding nutrition is & $60 \%$ & $51 \%$ \\
\hline 4. & The following statement which is correct regarding vitamin $\mathrm{E}$ is & $51 \%$ & $64 \%$ \\
\hline 5. & What is the definition of balanced nutrition & $70 \%$ & $79 \%$ \\
\hline 6. & The following statement which is correct regarding balanced nutrition is & $53 \%$ & $62 \%$ \\
\hline 7. & Which of the following statement is true regarding the balanced nutrition pyramid & $45 \%$ & $60 \%$ \\
\hline 8. & Which of the following statement is true regarding the consumption of carbohydrates and sugars & $32 \%$ & $34 \%$ \\
\hline 9. & Which of the following statement is true regarding the consumption of sufficient water & $23 \%$ & $40 \%$ \\
\hline 10. & Which of the following statement is true regarding the consumption of fat & $45 \%$ & $57 \%$ \\
\hline 11. & Which of the following statement is incorrect regarding the measurement to ensure food safety & $26 \%$ & $40 \%$ \\
\hline
\end{tabular}

Table 2. The analysis of participant's knowledge level in pre-test and post-test by Wilcoxon Signed Rank Test $(\mathrm{n}=53)$.

\begin{tabular}{ccccc}
\hline Knowledge & Mean \pm SD & Minimum & Maximum & P Value \\
\hline Pre-test & $46.25 \pm 20.69$ & 9 & 91 & $0.001^{*}$ \\
Post-test & $56.47 \pm 20.17$ & 18 & 100 & \\
*significant if $\mathrm{p}<0.05$ & & &
\end{tabular}

*significant if $\mathrm{p}<0.05$

Table 2 indicated the mean score of the participants. The mean score of pre-test showed less than $50 \%$ of the total score with the lowest score at 9 out of 100, which points out the lack of nutritional knowledge of participants. Based on the analysis result, it can be reported that there was a significant difference between pretest and post-test score $(\mathrm{P}=0.001)$ with an increased mean score up to $22.1 \%$. Of all the participants who did the pre-test, 21 participants had a score above the mean score and 32 of the participants had a score below the mean score. Meanwhile, for the post-test, 25 participants had a score above the mean score and 28 participants had a score below the post-test mean score. From the 53 participants, 32 participants had an increase of total score, 14 participants had the same score as previous test and 7 participants had a decrease total score from pre- 
test to post-test. It can be concluded that the health education regarding balanced nutritional intake to maintain immunity during a pandemic through webinar Serotonin 2021 was effectively succeed to increase the knowledge of participants by $60.4 \%$.

In line with the research conducted with a One Group Pretest-Posttest Design by Meirani et al. (2016) that showed a significant difference between the pre-test and post-test mean value with $\mathrm{p}=0.000$. They reported that health education could increase the knowledge of the respondents (Meirani, Wiyati, \& Himawan, 2016). The previous study with similar research design in elementary school reported the participants with a score of $39.1 \%$ before the socialization, became $47.8 \%$ after the socialization which indicated an increase in knowledge after the socialization (Jayanti, 2017). The research conducted by Hanifah (2015) with a One Group PretestPosttest Design also reported similar results, where there was a significant increase in the average scores before and after the socialization on the topic of balanced nutrition in middle school children with age ranging from 12-14 years old $(\mathrm{p}=0.000)$ (Hanifah, 2015). Sari et al. (2018) reported a significant difference in knowledge between before and after socialization $(\mathrm{p}=0.000)$ (Sari, Wulandari, Hidayat, Amelia, \& Yuriati, 2018). The result of this research is relevant with the result of the research conducted by Dianna et al. (2020) that reported a significant difference in knowledge before and after the intervention $(\mathrm{p}=0.001)$ (Dianna, Septianingsih, \& Pangestu, 2020). Previous research done by Aulya et al. (2019) also reported that there was an increase of wellinformed pregnant women. The percentage of pregnant women who had good knowledge before the socialization was $27.6 \%$ and after the socialization it was $79.3 \%(p=0.000)$ (Aulya, Suprihatin, \& Dianovianti, 2020). This is in relevance to the research results of Mardiyanto et al. (2019) which reported an increase in the average pretest and posttest scores from 55.6 to 88.7 (Mardiyanto, Latifah, \& Putri, 2019). Likewise, in a study in Toho sub-district on the manufacture of complementary foods with the same research design, it was found that there was a $32 \%$ difference in knowledge before and after being given a demonstration (Fitriani, Khotidjah, \& Pangestu, 2020). By conducting an Online Webinar using an online platform, there is a real time interaction between the speakers and the participants which will make the topic itself more interesting, interractive and easier to understand. If there are question from the participants, the questions will be answered by the speakers directly in the QnA session (Gupta \& Sengupta, 2021). The socialization and education given to the participants by an online platform contribute to the increase in knowledge regarding the topic discussed, or in this case regarding nutritional health based on the evaluation of the pre-test and post-test scores.

One of the factors that can affect the increase of the average score is age, where it can be seen that one of the inclusion factors in our study is young adults with an age range of 18-35 years old. Based on the demographical data, the majority of the participants are students. According to Notoatmodjo (2003), a person's ability to think will mature with age (Notoatmodjo, 2003 as cited in Andarmoyo, 2012). According to Mubarak (2011), one of the factors that influence a person's knowledge is age, where a person's grasping power and mindset will develop with age. In addition, according to Mubarak (2011), a person's level of education also affects knowledge, where the higher a person's education, the easier for that person to receive information (Mubarak, 2011). The amount of information received can be associated with the level of understanding, which then could affect one's behavior according to the knowledge one has (Notoatmodjo, 2003, as cited in Amelia, Nurchayati, \& Elita, 2014). According to Oktavia et al. (2017) the higher a person's education level, the easier to comprehend information and the easier to implement one's knowledge in one's behavior, especially in terms 
of health and nutrition. Thus, education also has a relationship with a person's attitudes and behavior (Oktavia, Widajanti, \& Aruben, 2017).

\section{Conclusion}

Health education through the SEROTONIN 2021 webinar increases the knowledge of the productive age community about balanced nutrition intake to maintain immunity during COVID-19 pandemic. Socialization and education towards a larger audience can be conducted to provide better representation of the level of knowledge and understanding regarding nutritional health in Indonesia.

\section{Acknowledgements}

We are grateful and would like to thank all of the parties involved in this study for their contribution in the implementation of the Community Service Program and the preparation of scientific articles.

\section{References}

Amelia, M., Nurchayati, S., \& Elita, V. (2014). Analisis Faktor-Faktor yang Mempengaruhi Keluarga Untuk Memberikan Dukungan Kepada Klien Diabetes Mellitus Dalam Menjalani Diet. Jurnal Online Mahasiswa Program Studi Ilmu Keperawatan Universitas Riau, 1(2), 8. Retrieved from Neliti: https://www.neliti.com/publications/188808/analisis-faktor-faktor-yang-mempengaruhi-keluargauntuk-memberikan-dukungan-kepa\#cite

Andarmoyo, S. (2012). Hubungan Pengetahuan Dengan Sikap Calon Buruh Migran/TKI Dalam Mencegah HIV/AIDS, PMS, dan Masalah Seksual Lainnya. Jurnal Florence, 5(2), 101. Retrieved from Muhammadiyah University of Ponorogo: http://eprints.umpo.ac.id/2047/4/Florence\%20Juli\%202012\%20\%28Sulistyo\%20Andarmoyo\%29.pd f

Aulya, Y., Suprihatin, S., \& Dianovianti, D. (2020). Perbedaan Pengetahuan Ibu Hamil Tentang Skrining Hipotiroid Kongenital Sebelum dan Sesudah Diberikan Penyuluhan Di Puskesmas Tanah Tinggi Kota Tangerang Tahun 2019. Journal for Quality in Women's Health, 3(2), 165-170. doi:10.30994/jqwh.v3i2.71

Badan Pusat Statistik (BPS). (2021, July 26). Hasil Sensus Penduduk Tahun 2020. Retrieved from https://www.bps.go.id/pressrelease/2021/01/21/1854/hasil-sensus-penduduk-2020.html.

Dewi, N., Maemunah, N., \& Putri, R. M. (2020). Gambaran Asupan Nutrisi Dimasa Pandemi Pada Mahasiswa. Jurnal Ilmiah Ilmu Kesehatan, 8(3), 369-382. doi:10.33366/jc.v8i3.1959.

Dianna, Septianingsih, N., \& Pangestu, J. F. (2020). Perbedaan Pengetahuan Ibu Balita Sebelum dan Sesudah Diberikan Penyuluhan Tentang Stunting Melalui Media Video dan Leaflet di Wilayah Kerja Puskesmas Saigon Kecamatan Pontianak Timur. Jurnal Kebidanan Khatulistiwa, 6(1), 7-15. doi:10.30602/jkk.v6i1.493.

Fitriani, H., Khotidjah, S., \& Pangestu, J. F. (2020). Perbedaan Pengetahuan Ibu Sebelum Dan Sesudah Diberikan Demonstrasi Pembuatan Pemberian Makanan Pendamping ASI (MP-ASI) Di Desa Benuang Kecamatan Toho. Jurnal Kebidanan Khatulistiwa, 6(1), 27-34. doi:10.30602/jkk.v6i1.507.

Gupta, S. K., \& Sengupta, N. (2021). Webinar as the Future Educational Tool in Higher Education of India: A Survey-Based Study. Technology, Knowledge and Learning, 1-20. 
Hanifah, D. L. (2015). Perbedaan Pengetahuan Remaja Sebelum dan Sesudah Diberikan Penyuluhan Tentang Gizi Seimbang Dengan Menggunakan Media Video di SMP Negeri 2 Kartasura. UMS Institutional Repository, 1-11. Retrieved from http://eprints.ums.ac.id/39799/12/NASKAH PUBLIKASI.pdf.

Irmawartini, \& Nurhaedah. (2017). Metodologi Penelitian. Retrieved from bppsdmk.kemkes.go.id: http://bppsdmk.kemkes.go.id/pusdiksdmk/wp-content/uploads/2017/11/Daftar-isi-MetodologiPenelitian_k1_restu.pdf

Jayanti, A. F. (2017). Perbedaan Tingkat Pengetahuan Gizi Seimbang Sebelum Dan Sesudah Penyuluhan Dengan Media Penyuluhan Roda Putar Gizi Dan Ketertarikan Pada Siswa Kelas III Di SDIT Al Istiqomah Tangerang. Retrieved from Politeknik Kesehatan Kementerian Kesehatan Jakarta II: https://perpus.poltekkesjkt2.ac.id/respoy/index.php?p=show_detail\&id=53\&keywords=.

Kementerian Kesehatan Republik Indonesia (Kemenkes RI). (2020). Panduan Gizi Seimbang COVID-19. Retrieved from https://infeksiemerging.kemkes.go.id/document/Panduan-Gizi-Seimbang-COVID-19$1127 /$ view

Mardiyanto, R. T., Latifah, N., \& Putri, A. A. (2019). Peningkatan Pengetahuan Gizi Seimbang Sebagai Pedoman Hidup Sehat pada Masyarakat di Sekitar Kelurahan Pondok Jagung Kecamatan Serpong Utara Kota Tangerang Selatan. Jurnal UMJ, 1-5. Retrieved from http://jurnal.umj.ac.id/index.php/semnaskat.

Megawati, G., \& Herawati, D. M. (2021). Pendampingan Pemenuhan Asupan Nutrisi Saat Pandemi COVID19 Pada Orang Dewasa Perkotaan. Jurnal Pengabdian Kepada Masyarakat, 5(1), 182-195. doi:10.29062/engagement.v5i1.597

Meirani, D., Wiyati, P., \& Himawan, A. (2016). Perbedaan Tingkat Pengetahuan Dan Sikap Ibu Hamil Sebelum Dan Sesudah Penyuluhan Mengenai IUD Pascaplasenta. Diponegoro Medical Journal (Jurnal Kedokteran Diponegoro), 5(4), 631-639. doi:10.14710/dmj.v5i4.14259

Mubarak, W. (2011). Promosi Kesehatan untuk Kebidanan. Jakarta: Salemba Medika.

Nurhaedah, \& Irmawartini. (2017). Metodologi Penelitian. Retrieved from Kementerian Kesehatan Republik Indonesia: $\quad$ http://bppsdmk.kemkes.go.id/pusdiksdmk/wp-content/uploads/2017/11/Daftar-isiMetodologi-Penelitian_k1_restu.pdf.

Oktavia, S., Widajanti, L., \& Aruben, R. (2017). Faktor-Faktor Yang Berhubungan Dengan Status Gizi Buruk Pada Balita di Kota Semarang Tahun 2017. Journal of Chemical Information and Modeling, 5(3), 186192. Retrieved from https://media.neliti.com/media/publications/163271-ID-faktor-faktor-yangberhubungan-dengan-st.pdf.

Perhimpunan Dokter Spesialis Gizi Klinik Indonesia (PDGKI). (2020). Panduan Praktis Penatalaksanaan Nutrisi COVID-19. 1st edn. Retrieved from Perhimpunan Dokter Spesialis Gizi Klinik Indonesia: https://litbangkespangandaran.litbang.kemkes.go.id/perpustakaan/index.php?p=show_detail\&id=360 0 .

Sauer, L. M. (2021). What Is Coronavirus? Retrieved from https://www.hopkinsmedicine.org/health/conditions-and-diseases/coronavirus.

Sari, T., Wulandari, F., Hidayat, M., Amelia, N. N., \& Yuriati, Y. (2018). Perbedaan Pengetahuan Ibu Sebelum dan Sesudah Diberikan Penyuluhan Tentang ASI Eksklusif di Wilayah Kerja Puskesmas Sidomulyo Rawat Inap Kota Pekanbaru 2018. Collaborative Medical Journal, 58-65. Retrieved from http://jurnal.univrab.ac.id/index.php/cmj/article/view/522/347

World Health Organization (WHO). (2020). Listings of WHO's Response to COVID-19. Retrieved from https://www.who.int/news/item/29-06-2020-covidtimeline. 